\title{
SETO PEOPLE IN THE EXPEDITION DIARIES AND LITERARY WORKS OF A RUSSIAN ÉMIGRÉ LEONID ZUROV
}

\author{
Irina Belobrovtseva \\ Professor, School of Humanities \\ Tallinn University, Estonia \\ irina.belobrovtseva@tlu.ee
}

\begin{abstract}
At the beginning of the twentieth century, after the October Revolution, more than one and a half million people left Russia. They lost their homeland forever, and this is why they often visited Estonia, as in this former province of the Russian Empire distinct 'Russian traces' could be found. This article examines the role of the émigré writer Leonid Zurov, who carried out archeological, restoration, and ethnographic work in the Pechorsky district in 1935, 1937, and 1938.
\end{abstract}

Keywords: archeological and ethnographical expeditions in 1930, Leonid Zurov, Pechory, Russian emigration, Seto people

\section{INTRODUCTION}

The experience of the beginning of the twentieth century was extremely important for Russian emigration: more than one and a half million people left their homeland after the October Revolution of 1917 and were scattered all over the world.

In 1920-1940 Russian emigrants, who had no opportunity to return to their homeland, at times visited Estonia, a former province of the Russian Empire, to meet their native culture.

One of these Russian emigrants was writer Leonid Zurov (1902-1971), who carried out archaeological, restoration, and ethnographic works in the Pechorsky district in 1935, 1937, and 1938. Zurov was born in the city of Ostrov, Pskovsky district, in 1902. He immigrated to Estonia in the late autumn of 1919 and moved on to Latvia in 1920. According to the Peace Treaty of 1920, both Estonia and Latvia received parts of the Pskov Province, and Pechorsky district was one of the territories left within the borders of Estonia.

In 1928 Zurov worked on the territory of Estonia, studying the PskovoPechersky monastery under the guidance of Vassily Sinaisky, a professor of 
Latvian University. The common mission of the research group was to preserve Russian culture in this area.

In 1929 Zurov moved to France at the invitation of a famous Russian writer, future Nobel Prize winner (in 1933) Ivan Bunin. His novel Kadet (Cadet) had been highly appreciated by literary critics of the Russian emigration, and Bunin himself recognized the 27-year-old writer Zurov as one of the most prominent writers of the young generation. Thus, with the help of Bunin's family, Zurov remained in France till the end of his life.

\section{THE 1935 EXPEDITION TO THE PECHORSKY DISTRICT AND THE FIRST MEETING WITH SETO CULTURE}

Besides his literary work, Zurov was attracted to the ancient history of Russia. In 1935 he undertook an expedition to Pechorsky district. He sent his drawings from Paris to the Pskovo-Pechersky monastery, trying to convince the prior to restore the monastery's belfry, which, according to his words, was 'mutilated'. The monastery appealed to the department for the protection of monuments under the Ministry of Public Education of Estonia, and the restoration was entrusted to Zurov. A large sum of money was donated for the restoration, and even the President of Estonia, Konstantin Päts, who belonged to the Orthodox confession, was one of the donators. Zurov sought necessary knowledge for the restoration works from ancient icons depicting the monastery buildings in all details, which he had found and copied in the monastery during his first visit there in 1928.

It is hard to believe that in just three months odd, Zurov did such a tremendous job. The solemn act of consecration of the restored belfry took place on September 8, 1935 (Zurov's visa was extended to meet this date). The Synod of the Estonian Apostolic Orthodox Church awarded him with the certificate of appreciation for the restoration of St. Nicholas Church.

Zurov developed no less activity outside the monastery. As a result, he discovered the remains of the ancient city near the village of Mitkovitsy. The pottery shards, bone products and other artifacts he had found there were sent to the archaeology office of the University of Tartu.

He was well aware of what kind of material traces of the Slavic past could exist in the Pechorsky district. But perhaps the most unexpected discovery for him was the culture of the Seto people. Having seen them for the first time in 1935, he was filled with a lively interest not only in his "own" Russian culture, but in rituals, faith, and customs of the "other" - small Seto people's - culture. The Seto used to live and still do in southeastern Estonia (a small group lives 
in the Pskovsky district of Russia). This is a small Finno-Ugric ethnic group, and their language is considered part of the Võro dialect of Estonian. At the same time, their Orthodox religion and customs are similar to those of Russians. Zurov was sure that the Seto performed ancient pagan rites common to them and the Slavs.

He enthusiastically describes the bright, elegant clothes of the Seto he saw at the Pechory bazaar:

Poluverki ${ }^{1}$ in white caftans, trimmed with red, in silk Russian shawls. The girls have plaited silk ribbons into their braids, and the women's hair is muffled, their eyebrows are covered with white bandages, "apostolniks". Women are proud, saying that they have old headdresses, like in the ancient icons of the Virgin. Cherry ribbons with tassels fall on the back from under their headscarves. (Zurov 1936a: 4)

Even after returning to France, he continued hearing the songs of Pechorsky district in his mind:

The road to Izborsk. Chudinki ${ }^{2}$ are returning from the market, driving horses, and the drunk peasant women in carts, dressed in white caftans, are tenderly hugging each other and singing all the way: 'Lela, Lela'.... praise and glory to the ancient Lel ${ }^{3}$. (Zurov 1936b: 21)

\section{ZUROV'S TRIPS TO ESTONIA AS A MEANS TO PRESERVE HIS NATIVE CULTURE}

Zurov's archeological and ethnographic contribution was extremely important. The inhabitants of the Soviet Pskovsky district, bordering on Pechorsky district, were evicted from their native villages, as a result of coerced collectivization. Their houses were partially destroyed and partially inhabited by people from other regions of Soviet Russia. Zurov wrote to one of his correspondents:

I've just come back from Lake Pskov. Went with the religious procession ... to the border of the USSR. ... Russian islands, the mouth of the River Velikaya, Pskov, Trinity Cathedral are perfectly visible. Behind the wire is the village of Poddubye, which was dispossessed last week, and the inhabitants were sent to Siberia. There's silence, a pear tree is blooming, the roof is open, the chimney is destroyed, glass has been shattered, and a frame is hanging. On a tower nearby a red flag is stretching in the wind; the Soviet border guard is looking at me through binoculars. ${ }^{4}$ (Zurov 1935a) 
He was surprised and at the same time he was sure that what he had seen would have been of undoubted value from the perspective of world culture. Later on, he wrote:

Returning to France [in 1935], I began a campaign in the name of saving the cultural values of the Pechorsky and Izborsky regions.

The Seto is an Estonian tribe that live near Izborsk. The Seto, as strange as it may seem, preserved ancient Slavic rites better than Russians. (Zurov 1947)

For Zurov, all this was a journey through time. From the burial mounds that disappeared after the land had been ploughed, the peasants dug out copper snake rings, copper necklaces, chains and plaques, and wide copper bracelets. The residents of Izborsk showed him hryvnias, Arab dirhams, weapons, pendants in the form of doves and ducks. He saw stone crosses, cut out of a solid slab at the Truvor ancient settlement. Ivan Bunin liked Zurov's photograph of a cross so much that he expressed a wish to have such a cross put on his grave.

Now Zurov was sure: his main task was to save the cultural values of his people from destruction, and he wanted to do the same also for the Seto people.

Returning to Paris, Zurov made several presentations, dedicated to the antiquities of the Pechorsky and Izborsky regions, such as "Drevnosti Izborskogo i Pechorskogo kraia v Estonii" (About the antiquities of the Pechorsky and Izborsky regions in Estonia) at Maison des Polytechniciens in Paris on January 26, 1936, and "Monastyrskie i tserkovnye drevnosti Pecherskogo kraia v Estonii" (Antiquities of monasteries and churches of the Pechorsky region in Estonia) at the Icon Association in Paris on February 7, 1936. He also published a number of relevant articles on these topics, such as "Iz istorii tserkvi Nikolaia Ratnogo v Pecherskom monastyre" (About the history of Nikolai Ratnyi Church in the Pskovo-Pechersky monastery) (Zurov 1935b); "Kak byl otkryt drevnii gorod, nosashchii nazvanie Gorodachok" (How was the ancient city, bearing the name of Gorodets, discovered) (Zurov 1935c); "O drevnostiakh Izborskogo i Pecherskogo kraia" (About the antiquities of the Pechorsky and Izborsky regions) (Zurov 1936c); and "Pechory" (Zurov 1936b).

At the same time he was intensively looking for like-minded people, possible partners to work in the Pechorsky district, in all countries of the Russian diaspora. He first found them in Prague, where, beginning in 1925, the Russian Archaeological Institute, Seminarium Kondakovianum, named by the famous Russian archaeologist Nikodim Kondakov, used to work, and then also at the University of Basel in Switzerland. Two historians, Nikolay Andreyev ${ }^{5}$ and Irina Okuneva ${ }^{6}$, and photographer František Dědič came to Pechory from Prague. Andreyev wrote to Zurov in reply to his letter that the Prague part of 
the expedition "will focus on the church antiquities and handicrafts" (Andreyev \& Belobrovtseva 2014: 30).

Zurov in reply reports:

Trocadero [i.e. Musée de l'Homme in Paris] is mainly interested in the ethnographic border and the Seto villages. We have to make purchases for the museum (costumes, utensils, etc.); it will be necessary to describe the pagan rites of the Chudes and take a lot of photographs. We'll have to make a number of excavations of ancient burial grounds. In addition to that we'll carry out archaeological investigation on the shore of Lake Pskov. (Andreyev \& Belobrovtseva 2014: 37)

Elsa Mahler ${ }^{7}$ from the University of Basel was also interested in Russian folk songs. Two members of the expedition, Leonid Zurov and Boris Wilde ${ }^{8}$, were from Paris. Everyone, except for the technical employee, were Russian emigres and all of them saw their goal in the research and preservation of Russian culture in this region. It should be emphasized that four of the five researchers, except for Irina Okuneva, were somehow connected with Estonia.

\section{THE MOST FRUITFUL INTERNATIONAL EXPEDITION TO PECHORSKY DISTRICT IN 1937}

The expedition to Pechory, organized in 1937 with the support of scientific organizations in France, Czechoslovakia, Switzerland, and Estonia, was a most productive one. The library and sacristy of the Pskovo-Pechersky monastery were examined during the expedition, and dozens of ancient settlements, burial grounds, chapels, stone crosses, and holy springs were revealed. On the basis of the expedition materials, numerous scientific and popular scientific articles, literary works, and a book about ancient Russian folk songs were published. About 400 items, either bought from the peasants or donated by them, were delivered to the Musée de l'Homme (Museum of Man) in Paris.

Like no one else, Zurov was a very suitable person for ethnographic expeditions. According to the memoirs of N. Andreyev, he had a wonderful way of talking to peasants, and he was well aware of the ancient churches of the region. Also he was already familiar with the people who collected ancient objects, and got along with them. He was attentive and people welcomed him.

Zurov went to Pechory before everybody else. Firstly, to meet other members of the expedition as an "old-timer", "veteran", and secondly, to get to the celebrations of the ancient pagan holiday, Midsummer Day, on June 24. In the morning after the Midsummer Night feast Zurov went to a sacred stone, where 
the sacrifice had already begun. The picture crashed into his memory: candles were burning, and many beggars and pilgrims, both Russians and Setos, had gathered. They hoped to be cured of illnesses: some put a hand on the stone, some leaned with their back, some with a shoulder. They kissed the stone, stood on it and sat on it. Long ago, the stone had had a footprint of a sole with five toes on it, but this part of the stone was broken. People lubricated the stone with butter, and put cheese, wool, and milk on the stone.

Zurov returned from his trip to the Pechorsky district in 1937 with a solid track record: he had bought samples of peasant textiles, embroidered towels and belts, mittens, wooden cups, a churn, a small birch bucket, wooden tools for weaving nets, samples of flax, etc., for the Musée de l'Homme in Paris. He brought with him Seto costumes and utensils, described the pagan rituals of the Seto in the expedition diary, and took hundreds of pictures.

This time he collected voluminous materials on toponymy, records of anthroponyms, and some words of the Seto language with translation into Russian. He photographed a Seto wedding in the village of Potalovo - the so-called bridal train that is a wedding procession, which departs from the house of the groom, heading for the bride's house, and thence to the place of the wedding. The photographs depicted a women's choir at the wedding, in colorful Seto national costumes and decorations, a wedding blacksmith who, according to an ancient custom, forged a horseshoe right at the wedding, in order for the marriage to last. Zurov registered sacred stones, springs and trees, collected information about plant dyes. Numerous sacred stones of the Pechorsky district were the subject of Zurov's special interest. He also captured in his photographs the sacrifice of wool at the Annakivi stone in the village of Sulmi.

Thanks to the trusting relationship he had with Russian and Seto peasants, he was even allowed to photograph the "erotic female dances". This was a name Zurov gave to folkloric role dances, for example, the bear dance, performed by three women, back to back, weaving the hems of dresses and caftans in the form of a phallus. In his field records we can find a detailed description of another dance:

One old woman lifted the hem of her coat on her back, got down on all fours and went to the other women, like a bull, spreading fingers and exposing them like horns, poking them into the ground, as if butting them. (Zouroff 1941: 297)

Everything he had seen and heard in the Pechorsky district breathed antiquity, and rituals and rites went back to time immemorial. Almost thirty years later, he wrote to his expedition companion Nikolay Andreyev: "I remember distant times. Revel, Izborsk, Pechory, and the shores of Lake Pskov. It was so easy to breathe then" (Andreyev \& Belobrovtseva 2014: 247). 
After three and a half months, Zurov returned to Paris, but his thoughts were still in the Pechorsky district. Less than a year later, some participants of the last expedition gathered there again. And in 1938 the expedition was successful. The results of Leonid Zurov and Boris Vilde's ethnographic and archaeological research have retained their significance to the present day and were published 70 years later by the joint efforts of scientists from three countries - France, Estonia, and Russia (Benfoughal \& Fishman \& Valk 2017).

When leaving Estonia in the autumn of 1938, Leonid Zurov was convinced that the work in the Pechorsky district had only just begun. He hoped to take part in an expedition with the Swedes the following summer. This plan was formulated as a result of his acquaintance with Knut Knutson, a Swedish librarian, who offered to publish the results of Zurov's archaeological research. So Zurov became the first researcher to acquaint Swedish scientists with the ethnography and archeology of the Pechorsky district, divided between Estonia and Russia after 1920. A voluminous article by Zurov, "Dyrkan av stenar, kallor och trad bland setukeser och ryssar i Petseri-omradet" (About the veneration of sacred stones and rills by the inhabitants of the Pechorsky district, Russian and Seto) appeared in the annual issue of the journal Folk-Liv in 1940.

Although before his field trip to the Pechorsky district in 1938 Zurov had had some difficulties in his relations with the authoritative French Slavist André Mazon, the results of the expedition were so impressive that his work was honored with written gratitude from the Minister of Public Education of France, Jean Zeya. In addition, the Musée de l'Homme hastened to give the researcher a grant, which remained in abeyance because of Mazon's negative expert feedback on the application for the needs of the expedition. Zurov immediately reported this to the Bunin family:

I hasten to please you. Yesterday came a letter from the Musée de l'Homme. Here is the text.

'I am pleased to inform you that at yesterday's (November 23, 1938) meeting of the Committee on missions, it was decided, at the request of Professor Privet, to provide you a grant of 12,000 francs. Please accept the assurances of my highest consideration.

Jacques Soustelle (Deputy Director of the Museum of Man).'9

It was all inspiring and promised the same favorable attitude of the Ministry of Education and the Musée de l'Homme the next year. But in 1939 scientific work was cut short because of the political events - all appropriations went on defense. France declared war to Germany immediately after the attack on Poland. On May 10, 1940, German troops launched a rapid offensive, and the defeated France was forced to sign an armistice on June 22. 


\section{THE FATE OF THE COLLECTIONS, THE FATE OF THE RESEARCHER}

The Musée de l'Homme carefully kept its collections during the war, as Zurov informed in his report on the survey of antiquities (see below about its fate): the collections "I deposited in the Trocadero Museum survived. During the war they were arranged according to topics, provided with records, stacked in boxes and hidden in the cellar from the Germans" (Zurov 1947). Also a part of his archive - sketches, field diaries, travel notebooks - was transferred to the custody of a good friend Tatiana Konyus, daughter of the composer Sergei Rachmaninov. The precious hundreds of negatives from 1935, 1937, and 1938, pictures of Pechory, which was heavily damaged during World War II, the photographs taken in the village of Meguzitsa in 1937-1938 - bathing in the sacred stream, sacrifice to Ivan stone, treatment of women and children at the stone - were preserved in museum collections. Zurov captured with his camera some moments extremely important for ethnographers: Seto warlocks (1937); treatment of the child with a thunderbolt by the healer Dubrovsky in the village of Lezgi (1938); funeral ceremony of a fisherman in the village of Lisya, which entailed sending his body out in a rook boat (1938).

In 1939 only Elsa Mahler was able to go to Estonia from Switzerland, and after the war Pechory and Estonia as a whole became Soviet. The Soviet Union was a closed territory for the Russian emigrants and Zurov, who had done so much investigating the border culture in Pechory, never saw it again.

Leonid Zurov's activity in Pechorsky district was significant not only because of the valuable results, but also because of his devotion to native culture and the ability to respect and accept the culture of 'other' people. During his four expeditions $(1928,1935,1937,1938)$ Zurov managed to collect unique materials about the remnants of ancient and medieval art, burial complexes and cultural facilities of the Pechorsky district. This was a zone of active ethno-cultural contacts of Slavic and Ugro-Finnish tribes, a special cultural space. Hence many pieces of evidence of the antiquity were destroyed during the war and, as a result of subsequent land reclamations, Zurov's information turned out to be almost unique. He was one of the pioneers of the stone-age research in the Pechorsky district, where he had found a number of stone hammers and dozens of stone crosses on burial grounds, many of which have not survived up to our time. He was the first to conclude that many elements of the Russian folk dress were preserved in the Seto national costume, and ethnographer E. Richter came to the same conclusions in the 1960s (Richter 1961, 1976).

The inability to continue engagement in the fieldwork and the ethnographic and archaeological research in the Pechorsky district encouraged Leonid Zurov to apply to the Academy of Sciences of the USSR with a voluminous report on 
the survey of antiquities of the Pechorsky and Izborsky districts, on the restoration of the belfry of the Church of Nikolai Ratnyi in the Pskovo-Pechersky monastery and the results of archaeological and ethnographic exploration in 1935,1937 , and 1938. In the report he recorded not only the huge amount of work done by the expeditions, but also offered prospects for further scientific work in this direction. Zurov saw the following as one of these perspectives in the study of the history and culture of the Seto people:

The Seto tribe, who lived in the forests near Izborsk, adopted Orthodoxy from the inhabitants of Izborsk and Pskov on pain of paying a penalty for disobedience: in each village for the newly baptized, a wooden chapel was erected on the site of pagan services, and a stone cross in it. But the Seto only called themselves Christians, but in fact had remained pagans for a long time. ... The remnants of this tribe, the baptized Seto, who were called 'half-believers' by the inhabitants of Izborsk for their adherence to pagan rites, still live in the area of Izborsk. ... Seto women perfectly preserved their language, customs and songs. This small endangered ethnos needs a special study. The ancient rites, lost by the Slavs, have survived among the Seto. (Zurov 1947)

Leonid Zurov gave his report and some other materials of expeditions to the Soviet Embassy in France for their subsequent transfer to Soviet scientific organizations, primarily to the Academy of Sciences. However, "when it became known that L.F. Zurov was not going to take Soviet citizenship and return to the USSR, all documents and materials ... were returned to him through the Chairman of the Central Board of the Union of Soviet Patriots" (Ponomarev 2014: 20).

\section{CONCLUSION}

The first studies on the culture of the first wave of Russian emigration were made by foreign researchers (Raeff 1990; Karlinsky \& Appel 1977; Schlögel 1994, 1998; Andreyev \& Savicky 2004). Russian first-wave emigrants did their best to preserve their culture in their families and Russian communities in the countries of residence. The peculiarity of their reality perception was that along with their own, they tried to preserve other historically close cultures. Leonid Zurov's fascination by the history, rituals, and culture of the small Seto people, who preserved their originality in everyday life between Estonians and Russians, was reflected in his diaries, field notes, and articles. On the one hand, Zurov was the discoverer of this small people for the Western world, as much as for the huge Russian-speaking diaspora formed in the world after the 
October revolution of 1917. On the other hand, the young writer and archaeologist received an inspirational boost: the centuries-old Russian culture can be preserved in the Russian diaspora despite the policy of the Soviet authorities to demolish it, extrapolating the viability of the Seto, their efforts to preserve their culture, following their customs and rituals under the circumstances of emigration.

\section{ACKNOWLEDGEMENTS}

This study was supported by the Estonian Ministry of Education and Research (Estonia between East and West: The Paradigm of the Images of "Own", "Other", "Strange", "Enemy" in Estonian Cultures in the 20th Century; IUT 18-4), and by the European Union through the European Regional Development Fund (Centre of Excellence in Estonian Studies - TAU-16078).

\section{NOTES}

1 Poluverki - half-believers, thus the Russians called the representatives of the Seto people.

${ }^{2}$ Chudinki - another name for the Seto given to them by Russians, a diminutive from 'Chud', which is a collective old Russian name of Finno-Ugric tribes, cognate with 'chuzhoi', i.e. 'alien'.

${ }^{3}$ Lel' - Slavic deity of love and/or marriage.

${ }^{4}$ L.F. Zurov's letter to V.N. Bunina from June 6, 1935 (LRA. MS 1068/2073).

5 Nikolay Andreyev (1908-1982) - Russian historian of the Middle Ages. He left Russia with his parents after the revolution, in 1919. Andreyev graduated cum laude from the Russian Gymnasium in Tallinn in 1927 and from the Philosophy Faculty of Charles University in Prague in 1931. In 1933 he received his doctorate in philosophy from the Charles University. He worked at the N.P. Kondakov Archaeological Institute as the head of the library, academic secretary, and in 1939-1945 as director. In 1945 he was arrested by Soviet military counterintelligence, and spent two years in Soviet prisons in Germany. Upon his release, he lived briefly in Berlin. In 1948 Andreyev was invited to teach at the Slavic Department of the University of Cambridge. He was the founder and the first editor of the almanac Nov' (Tallinn, 1928-1932). Andreyev authored a large number of works on Russian history and literature, as well as the memoir To, chto vspominaetsia (What comes to mind; Tallinn 1996).

6 Irina Okuneva (1913-1941) - art historian, specialist in the field of iconography. She was born in St. Petersburg, emigrated from Russia in 1922 and graduated from the Charles University in Prague. In 1938 she moved to Belgrade, married historian D. Rasovski. Both of them worked in the Belgrade department of the N.P. Kondakov Archaeological Institute, and both were killed in a German bomb raid. 
7 Elsa-Eugenie Mahler (1882-1970) was born in Moscow. Her father Josef Mathias Eduard Mahler was a merchant-engineer, originally from Switzerland. Her mother, born Louise Sivers, originated from Baltic Germans. She was a scholar of Slavic studies and folk arts, and came to Switzerland either in 1919 or in 1920, and received her doctoral degree at Basel University in 1924. In 1937-1939 Mahler participated in the archaeological and ethnographical expeditions in Pechorsky district to collect Russian folk songs. She was the author of the book Altrussische Volkslieder aus dem Pecoryland: Fur Gesang a cappella (Basel 1951) and a large number of articles about folklore and ethnography of the Russians in Pechorsky district. She was the founder of the Russian Library and Russian Seminar at the University of Basel. In 1938 Mahler became the first woman to be appointed to a professorship at the University of Basel.

8 Boris Wilde (1908-1942) - Russian author, ethnologist. He was born in Russia, but in 1919 Wilde's family emigrated to Estonia, to the town of Tartu. In Tartu Wilde graduated from the Russian gymnasium. His literary debut dates back to that time. In1930 he moved to Germany and in 1932 - to France. He was engaged in ethnology at the Musée de l'Homme in Paris, participated in Pechory expeditions with Leonid Zurov in 1937 and 1938. In 1941 Wilde became one of the founders of the anti-Hitler movement Résistance (soprotivlenie), and a publisher of a newspaper under the same name. $\mathrm{He}$ was executed by the Nazis and was posthumously awarded the medal of Resistance.

9 The original reads: Il m'est agréable de vous faire connaître que la Comission des missions qui s'est réunie hier (23 Novembre 1938), a décidé, sur la requête du Professeur Privet, de vous accorder une subvention de 12.000 fr. Croyez, je vous prie, á mes sentiments les plus distingués. Jacques Soustelle (v. direct. Musée de l'Homme) (LRA. MS 1068/2112).

\section{REFERENCES}

Andreyev, Catherine \& Belobrovtseva, Irina (comps. \& eds.) 2014. "Tol'ko Vy poimete sleduiushchii tekst”: Perepiska N.E. Andreeva i L.F. Zurova. [“Only You Will Understand theFollowing Text...”:N.E.Andreyev's andL.F.Zurov's Correspondence.] Baltiiskii Arkhiv: Russkaia kul'tura v Pribaltike 13. Tallinn: Avenarius. Andreyev, Catherine \& Savicky, Ivan 2004. Russia Abroad: Prague and the Russian Diaspora, 1918 - 1938. New Haven: Yale University Press.

Andreyev, Nikolai 1996. To, chto vspominaetsia. [What Is Remembered.] In 2 vols. Tallinn: Avenarius.

Benfoughal, Tatiana \& Fishman, Olga \& Valk, Heiki (comps.) 2017. Inimese Muuseumi ekspeditsioonid Eestisse. Boris Vilde ja Leonid Zurov Setomaal (1937-1938). [Expeditions of the Museum of Man to Estonia. Boris Vilde and Leonid Zurov in Setomaa (1937-1938).] Seto Instituudi Toimetised 2. Tartu: Tartu Ülikooli ajaloo ja arheoloogia instituut, Seto Instituut.

Karlinsky, Simon \& Appel, Alfred 1977. The Bitter Air of Exile: Russian Writers in the West 1922-1972. Berkeley \& Los Angeles \& London: University of California Press.

Ponomarev, Andrei (ed.) 2014. L.F. Zurov: Stat'i i pis'ma. [L.F. Zurov: Articles and Letters.] I. Moscow: n.p.

Raeff, Marc 1990. Russia Abroad: A Cultural History of the Russian Emigration, 19191939. New York \& Oxford: Oxford University Press. 
Richter, Elizaveta 1961. Material'naia kul'tura setu v XIX-nachale XX veka (k voprosu ob etnicheskoi istorii setu). [The Material Culture of the Setu in the 19th and the Beginning of the 20th Century (to the Issue of the Ethnic History of the Setu).] Abstract of the thesis for the degree of candidate of historical sciences. Moscow \& Tallinn: Akademiia nauk Estonskoi SSR.

Richter, Elizaveta 1976. Russkoe naselenie Zapadnogo Prichud'ia (Ocherki istorii material'noi i dukhounoi kul'tury). [Russian Population of the Western District of Lake Peipus (Sketches of History, Material and Spiritual Culture).] Tallinn: Valgus.

Schlögel, Karl (ed.) 1994. Der grosse Exodus: Die russische Emigration und ihre Zentren 1917 bis 1941. Munich: C.H. Beck Verlag.

Schlögel, Karl 1998. Berlin, Ostbahnhof Europas: Russen und Deutsche in ihrem Jahrhundert. Berlin: Siedler Verlag.

Zouroff, Leonid 1941. Dyrkan av stenar, källor och träd bland Setukeser och Ryssar i Petseri-omrädet. [About the Veneration of Sacred Stones and Rills by the Inhabitants of the Pechorsky District, Russian and Seto.] Folk-Liv: Acta ethnologica et folkloristica Europaea, Vol. 4, pp. 62-76.

Zurov, Leonid 1935a. L.F. Zurov's Letter to V.N. Bunina from June 6, 1935. LRA. MS 1068/2073.

Zurov, Leonid 1935b. Iz istorii tserkvi Nikoly Ratnogo v Pecherskom monastyre. [About the History of Nikolai Ratnyi Church in the Pskovo-Pechersky Monastery.] Nov', Vol. 8, pp. 93-98.

Zurov, Leonid 1935c. Kak byl otkryt drevnii gorod, nosiashchii nazvanie Gorodachek. [How Was the Ancient City, Bearing the Name of Gorodets, Discovered.] Nov', Vol. 8, pp. 98-102.

Zurov, Leonid 1936a. Izborskaia zemlia. [Izborsk Land.] Poslednie novosti, No. 5581, p. 4.

Zurov, Leonid 1936b. Pechory. [Pechory.] Illiustrirovannaia rossiia, Vol. 31, p. 21.

Zurov, Leonid 1936c. O drevnostiakh Izborskogo i Pechorskogo kraia. [About the Antiquities of the Pechorsky and Izborsky Districts.] Poslednie novosti, No. 5652, p. 4.

Zurov, Leonid 1947. Zapiska L.F. Zurova o proizvedennom im obsledovanii drevnostei Pechorskogo i Izborskogo kraia, o restavratsii zvonnitsy tserkvi Nikly Ratnogo $v$ Pskovo-Pecherskom monastyre i o rezul'tatakh arkheologicheskoi i etnograficheskoi razvedkiv 1935, 1937 i $1938 \mathrm{gg}$. [Report on the survey of antiquities of the Pechorsky and Izborsky districts, on the restoration of the belfry of the Church of Nikolai Ratnyi in the Pskovo-Pechersky monastery, and the results of archaeological and ethnographic exploration in 1935, 1937 and 1938.] LRA. MS 1068/751.

\section{ARCHIVAL SOURCES}

LRA. MS - Manuscript collection of the Russian Archive of Leeds University (collections of I.A. Bunin, V.N. Bunina, L.F. Zurov, and E.M. Lopatina).

Irina Belobrovtseva is Professor Emeritus at Tallinn University, and senior research fellow $(\mathrm{PhD})$ of the Centre of Excellence in Estonian Studies at the Estonian Literary Museum, Estonia. Her main research areas are cross-cultural ties, history and culture of Russian emigration, and self-identity in diaspora communities.

venefil@tlu.ee 